\title{
The Role Of Growth In Long Term Investment Returns
}

\author{
John Paul Broussard, (Email: broussar@crab.rutgers.edu), Rutgers University
}

David Michayluk, (Email: dave@uri.edu), University of Rhode Island

Walter P. Neely, (Email: neelywp@millsaps.edu), Millsaps College

\begin{abstract}
Stocks with a high valuation compared to fundamental values imply a high growth rate, yet these stocks have typically under-performed in subsequent years supporting Lakonishok, Shleifer and Vishney's (1994) contrarian investment strategies. The precise definition of growth and subtle differences of measuring growth are explored in assessing the role of growth in long-term investment decisions and stock valuation. Results from a later period and with additional tests than employed by $L S V$ indicate that growth is a primary valuation factor, and valuation measures such as E/P and $B / M$, are imperfect proxies for expected growth. Growth appears mean reverting, but investors do not seem able to discern changes in growth rates and this miss-specification of expected growth may help explain the superiority of value versus growth strategies. In addition, investors' naïve extrapolations of past growth provide explanatory power in future holding period returns.
\end{abstract}

\section{INTRODUCTION}

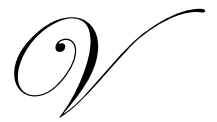

alue investing and growth investing are styles that favor firms with opposite growth profiles. Stocks with low earnings relative to prices $(\mathrm{E} / \mathrm{P})$ and lower book value relative to market value $(\mathrm{B} / \mathrm{M})$ are classified as growth (or glamour) stocks since much of the current price is from perceived growth prospects and not current earnings. High E/P and B/M stocks are classified as value stocks and these stocks have low growth prospects since their price reflects current earnings with little premium for growth. This implied growth valuation by investors suggests that investors anticipate continuing improvements in operating performance. Typically, operating performance can be measured by variables such as earnings, assets or sales.

The high market valuation accorded to growth stocks is puzzling at times, since high prices in excess of fundamental values indicate investors believe high growth rates are sustainable. High growth rates should entice competitive market forces and increase risk, thereby reducing future growth of these companies. While some studies provide support for growth investing, such as Peters (1991), many others (Basu (1977), Jaffe, Keim, and Westerfield (1989), Chan, Hamao, and Lakonishok (1991), Fama and French (1992), Capaul, Rowley and Sharpe (1993), Lakonishok, Shleifer and Vishny (1994) [LSV hereafter], Haugen (1995) and Bauman, Conover and Miller (1998)) reveal that value stocks earn higher returns. Value stocks, defined by high $\mathrm{B} / \mathrm{M}$ and $\mathrm{E} / \mathrm{P}$, and presumably slower growth (although not tested in these studies), consistently outperform growth stocks over the long term.

The superiority of value strategies can be explained either by a hidden specification of risk, or by a misspecification of growth manifest by investors' behavior. ${ }^{1}$ Fama and French (1992) suggest that the greater returns of value stocks are due to higher risk. Simply stated, high B/M is a proxy for high risk. This result contradicts the constant growth valuation model, leading to the conclusion that low B/M firms (associated with high growth) have higher expected and required returns, hence higher risk. ${ }^{2}$ Alternatively, behavioral explanations relate investors' overreactions to past operating results in a similar manner to their overreaction to past price behavior (see DeBondt and Thaler (1985, 1987)). Growth stock investors believe that high past growth in operating performance will continue unabated, even when the high growth rates are unlikely to be sustained beyond one to two post-formation years (LSV). 
Much of the focus of growth has been concentrated on earnings. Chan, Karceski and Lakonishok (2001) find "no persistence in long-term earnings growth beyond chance." LaPorta, Lakonishok, Shleifer and Vishny (1997) find that earnings announcements that differ from expectations account for $25-30 \%$ of the premium earned by value stocks. Dechow and Sloan (1997) study analysts and find that the earnings estimates for growth firms are somewhat optimistic, and that those for value firms are on average pessimistic. These papers indicate that there may be an extrapolation bias built into investor expectations of growth, and this phenomenon may help explain why value firms outperform growth firms.

In examining the value versus growth investing phenomenon, this paper concentrates on the explicit link between growth and long-term investment performance and contributes to the literature in three ways. First, different actual measures of growth are examined without a predisposition to only consider earnings growth. Second, data used in this analysis is from the pre-internet period and extends the data used by LSV. The time period is important since the internet boom is often characterized as a period with many day traders, an explosion in the number of listed companies and a very short-term investment focus on earnings that culminated in a bubble that inflated and burst. By using earlier data, this paper does not put an undue influence on this time period. Third, in measurements of growth, mean reversion is identified that may partially explain the value versus growth phenomenon. Fourth, naïve extrapolations of past growth are revealed produce counterintuitive results in future holding period returns. The paper proceeds as follows. Section two examines the value versus growth investment philosophies. In section three, the definitions of growth and hypotheses to be tested are identified. Methodology is specified in section four. Results are presented in Section five, while Section six concludes.

\section{VALUE VERSUS GROWTH}

Value strategies favor the purchase of stocks with low prices relative to fundamental values. Graham and Dodd (1934) may be the earliest reference, but it wasn't until the early 1990s that academic interest increased following the studies by Basu (1977), Fama and French (1992) and LSV. Basu (1977) finds the risk-adjusted returns for low P/E stocks (associated with low growth) exceed those for high P/E stocks (associated with high growth). With the explanatory power of beta questioned, Fama and French reveal the book to market ratio as a measure of price relative to fundamental value that provides explanatory power in the cross-sectional distributions of security returns.

Some early studies (Little (1962), Lintner and Glauber (1967) and Little and Rayner (1966)) connected growth and valuation. These studies find that future earnings, and hence, earnings growth rates, cannot be forecast due to the "random walk of earnings". Insignificant benefits accrue to those connecting growth forecasts to valuation. However, in a follow-up study, Fuller, Huberts, and Levinson (1992) find that high E/P (value) stocks have lower earnings growth rates.

There is no consensus on the explanation of value stocks' superior performance, with at least three different explanations in the literature. Fama and French (1992) suggest that performance is related to risk. But there are conflicting risk relationships at least with beta. Capaul, Rowley and Sharpe (1993) find a negative relationship between $\mathrm{B} / \mathrm{M}$ and beta, while Harris and Marston (1994) control for growth and find a positive relationship between B/M and beta. This contradictory evidence does little to illuminate the connection between risk, return, and growth illustrated by the constant growth valuation model

Second, LSV conclude that the behavior of individual and institutional investors causes the value/growth investment phenomenon. Growth investing lures individual investors. Institutional investors are also lured, but their motivations may not be only a desire for a high return, but also a desire for appearing prudent. Managers are less likely to be criticized if they have invested in stocks currently favored in the market. LSV imply that the herd's inherently transitory opinions ebb and flow with changes in the marketplace, causing growth holdings to move in and out of favor.

Third, the superior performance of high $\mathrm{E} / \mathrm{P}$ and $\mathrm{B} / \mathrm{M}$ strategies could also be a behavioral manifestation of overreaction as documented by Jegadeesh and Titman (1993). They find that positive feedback returns dissipate within 
two years such that employing strategies that work against the consensus of the market may be more effective in the long run. This finding is similar to DeBondt and Thaler's $(1985,1987)$ contrarian strategy.

The key to understanding the value versus growth puzzle may be to examine growth in more detail. Haugen and Baker (1993) demonstrate that growth is mean reverting and mis-pricing may occur since high (low) growth prospects are subsequently revised, resulting in price declines (increases). This explanation of mis-pricing is not universally supported. Harris and Marston (1994) find that mis-pricing is not a valid explanation for the value/growth investment puzzle since portfolios based on differences in analysts' growth expectations have no return advantages. In contrast, Dechow and Sloan (1997) find evidence of mean reversion and the incorporation of analysts' growth expectation biases.

The missing link may be to examine growth and fundamental valuation variables along with long term holding periods. This paper looks at growth as a primary factor that may drive the $\mathrm{E} / \mathrm{P}$ and $\mathrm{B} / \mathrm{M}$ results found in the literature. Relating growth to valuation measures is addressed in the next section of the paper.

\section{GROWTH HYPOTHESES}

Existing literature reveals that a variety of variables (beta, E/P, B/M, cash flow, sales growth and size) contribute some explanatory power to understanding stock returns. But the relationship between definitions of growth in operating performance and long-term holding period returns is not well identified in the literature. LSV examine sales and cash flow growth and the relationships with long-term returns, but they do not test asset or EPS growth and the relationship to long-term returns. This paper augments the LSV analysis of sales growth by examining the persistence of sales earnings and asset growth. In addition, the paper also re-examines LSV's naïve extrapolation hypothesis using past and future growth.

This paper addresses three main questions. First, are various definitions of growth related to stock returns? Second, do high growth rates indicate superior firm investment opportunities through extrapolation of growth or, alternatively, does high growth attract investors who then bid up prices and lower returns? Third, can growth be used to help explain the superiority of value investment strategies?

For the first question, in order to determine the relationship between growth and stock returns, the a priori relationship can be expected to be positive or negative. If growth indicates increased opportunities for the firm, then a positive relationship between growth and returns should exist assuming the growth potential is not already included in prices. Alternatively, growth may indicate opportunities for competitors, and therefore there future growth will come at the expense of holding period returns. If publicly traded companies operate in competitive markets, then high growth may signify profitable opportunities. If firms are profitable, additional firms enter until economic profits are driven to zero. An exception would be for companies with monopoly power due to the industry or patents. Several different growth definitions (earnings, assets and sales) within this economic framework are used to determine the impact on holding period returns for long-term investment horizons. Asset growth is examined because it is an indicator of the long-term trend in the success of a firm. Sales growth is examined since sales are the basis of future (growth in) profits and earnings and may be the easiest variable for a firm to influence. Growth in these fundamental variables impacts shareholder valuation, at least in the long run.

To answer the second question about high growth rates attracting investors for superior or inferior returns, investor behavior and naïve extrapolations of growth rates and stock valuation over long horizon holding period returns are examined. According to LSV, investors over-extrapolate future growth rates. Firms with high past growth rates are expected to have high future growth rates, and this continuation is reflected in variables such as E/P and B/M.

For the third question of the use of growth to explain the superiority of value investment strategies, past and future growth is considered. Because extrapolation errors can occur, the relationship between naïve extrapolations of past growth and long horizon holding period returns is examined. 
In sum, the questions are answered by examining investors' responses to growth by testing for errors in growth rate expectations and how the errors relate to long horizon holding period returns.

\section{METHODOLOGY}

The Compustat 1995 annual tapes are used to obtain earnings, book value, sales, and total asset values for all firms with valid data on the Industrial and Research Tapes. Since the focus is on long horizon (5-year) growth rates and holding period returns, the analysis contains portfolios formed only during the years 1981 to 1990 and analyzing growth from 1981 to 1995. Portfolios are formed three months after company fiscal year ends and are held for five years without annual rebalancing. Firms are deleted from the sample if they do not contain valid pre- and post-portfolio formation data for five years, or if they do not have valid data on the 1995 CRSP data tape. 9,197 firm-years of data are used in the analysis. Firms are allocated to quintiles ranked by E/P, B/M, growth, and other variables.

Compound annual growth rate calculations are corrected for negative values and high volatility by employing the growth rate calculation procedure used by Dechow and Sloan (1997). The approach to calculating growth rates is illustrated in Brigham and Houston (2004). Five-year growth rates are calculated for earnings, assets and sales using a least-squares approach that fits a line among the six annual data points of interest. For example, to calculate a historical annualized compound growth rate for the time period of interest, all data points from 5 years prior to the current year are used. A least squares fit of those data against time is then estimated and the slope of the regression line indicates the growth rate. If data for the beginning observation and the current observation are missing or negative, then that firmyear is dropped from the sample. Future growth rates are also calculated in a similar manner except that the six data points originate with the current observation and look forward 5 years.

LSV, who analyze the earlier period 1968 to 1989, suggest that investors make naïve growth extrapolation errors when pricing securities. They state that growth stocks' earnings (sales and cash flow) grows faster for one to two years than for value stocks. Investors extrapolate the growth to continue, but for years 3-5 growth in earnings is similar for both growth and value companies. LSV do not extend their test of this naïve extrapolation hypothesis to examine return effects or to examine interactions between variables. If stock holding period returns are a function of fundamental valuation variables and growth rate values, then a cross sectional regression analysis may indicate the significance of growth and/or valuation measures. Long-horizon holding period returns may also be a function of other variables such as size factors and growth rate effects. The growth rate effects are modeled using past growth rate values as a proxy for future growth rate expectations, and errors from a naïve growth rate extrapolation model. The naïve growth errors are generated by a simple OLS regression of future growth rates onto historical growth rates. Using the previously realized growth rate calculation along with naïve extrapolation errors gives unique insight into the relationship between long horizon holding period returns and the role played by various measures of growth.

\section{RESULTS}

Table 1 displays the overall correlation relationship between the holding period returns, growth rates, E/P, $\mathrm{B} / \mathrm{M}$, market values and stock prices for firms having valid past and future growth rates. Across all firms and across all time periods (all firm-years), there exists a statistically significant positive correlation between holding period returns and future growth rates. Returns are negatively associated with past growth of earnings and assets, but positively associated with past sales growth.

One of the most interesting correlation relationships exists between the past and future growth rate variables. Past earnings growth is negatively correlated with future earnings growth, but positively correlated with future assets and sales growth. Past asset and sales growth rates are positively correlated with future asset and sales growth rates. This result may indicate that earnings figures contain more of a temporary component (random, non-predictive) and are more responsive to short-term changes, rather than the permanent growth component found in assets or sales figures. Earnings that are very low or negative during some years may skew results based on large percentage swings in earnings. Historical sales and asset growth seem to be better predictors not only of future sales and assets growth, but also of earnings growth. Future returns are highly correlated with future growth in sales, earnings and assets, and future growth 
in assets and sales are correlated with past growth, especially of sales, so past growth may be a guide to stock valuation. $\mathrm{E} / \mathrm{P}$ and $\mathrm{B} / \mathrm{M}$ do not appear to be good growth correlates.

Next, the effects of $\mathrm{E} / \mathrm{P}$ and $\mathrm{B} / \mathrm{M}$ on future holding period returns and past growth rates are analyzed. As shown in Table 2, the E/P and B/M grouped results are consistent with the extant literature. Stocks are categorized in quintiles ranked by $\mathrm{E} / \mathrm{P}$ or $\mathrm{B} / \mathrm{M}$ and the results reveal that high $\mathrm{E} / \mathrm{P}$ and $\mathrm{B} / \mathrm{M}$ stock portfolios (value stocks) outperform the low $\mathrm{E} / \mathrm{P}$ and $\mathrm{B} / \mathrm{M}$ stock portfolios (growth stocks). A measure of risk for each quintile, the coefficient of variation (CV), is calculated as the quintile cross sectional standard deviation divided by the quintile mean. Not only do the value stock portfolios outperform growth stock portfolios in units of raw return; they also outperform in terms of risk per unit of return. For example, the high E/P (quintile 5) portfolio delivers more return (154\% vs. 112\%) than the low E/P (quintile 1) portfolio, but at a lower risk as measured by the coefficients of variation (135\% vs. $162 \%)$. A similar result is manifest when the data are grouped according to the $\mathrm{B} / \mathrm{M}$ ratio. The high $\mathrm{B} / \mathrm{M}$ value portfolio delivers a return of approximately $166 \%$ whereas the low B/M portfolio only delivers a $108 \%$ return on investment. The cost of that higher performance is $139 \%$ standard deviation per unit of return vs. a cost of $155 \%$ standard deviation per unit of return for the low B/M portfolio.

\section{Table 1: Correlation Relationship Between Variables of Interest}

This table presents the simple correlation coefficients between variables of interest. Variable acronyms are defined as follows. HPR represents the 5-year holding period return of each 9197 firm-year observations with available data from COMPUSTAT and CRSP over the 1976 to 1996 time periods. EP represents the Earnings-to-Price ratio, BM represents the Book-to-Market ratio, EPSGP and EPSGF represent past and future 5-year growth rates in Earnings per Share respectively. ASSTGP and ASSTGF represent past and future 5-year growth rates in total firm assets respectively. SALEGP and SALEGF represent past and future 5-year growth rates in total firm sales respectively. MKTVAL and PRICE represent the corresponding market value of each firm and the price per share of each firm when added to the portfolio for analysis.

Earnings, assets and sales growth rates are calculated using OLS regressions to fit a line between the logarithm of the most recent reported value of earnings, assets or sales with the previous or future 5 years reported values. Earnings per share and book value data were obtained from COMPUSTAT for each firm at its fiscal year end. Price data were obtained from CRSP and adjusted for stock splits or dividends when firms were added to the portfolio 3 months after fiscal year end. Holding period returns are buy-and-hold returns and include all dividends and distributions.

\begin{tabular}{|c|c|c|c|c|c|c|c|c|c|c|}
\hline & EP & BM & EPSGP & EPSGF & ASSTGP & ASSTGF & SALEGP & SALEGF & MKTVAL & PRICE \\
\hline HPR & 0.01 & $0.04 * * *$ & $-0.04 * * *$ & $0.43 * * *$ & $-0.03 * * *$ & $0.26 * * *$ & $0.03 * * *$ & $0.22 * * *$ & $-0.03 * * *$ & -0.00 \\
\hline EP & & 0.00 & 0.02 & -0.01 & 0.00 & $-0.03 * * *$ & 0.01 & $-0.04 * * *$ & 0.00 & 0.00 \\
\hline $\mathrm{BM}$ & & & -0.00 & 0.02 & $-0.028 * * *$ & -0.00 & $-0.02 *$ & -0.00 & -0.01 & -0.00 \\
\hline EPSGP & & & & $-0.26^{* * *}$ & $0.38 * * *$ & $0.20 * * *$ & $0.43^{* * *}$ & $0.10^{* * *}$ & 0.01 & $0.08 * * *$ \\
\hline EPSGF & & & & & -0.01 & $0.30 * * *$ & $-0.04 * * *$ & $0.27 * * *$ & $-0.02 *$ & 0.02 \\
\hline ASSTGP & & & & & & $0.204 * * *$ & $0.78 * * *$ & $0.25 * * *$ & $-0.03 * * *$ & $0.03 * *$ \\
\hline ASSTGF & & & & & & & $0.21 * * *$ & $0.60 * * *$ & $-0.04 * * *$ & $0.04 * * *$ \\
\hline SALEGP & & & & & & & & $0.19 * * *$ & $-0.05 * * *$ & $0.03 * *$ \\
\hline SALEGF & & & & & & & & & $-0.06^{* * *}$ & 0.01 \\
\hline MKTVAL & & & & & & & & & & $0.10 * * *$ \\
\hline
\end{tabular}

significant at a level of $\alpha=0.10 ;{ }^{* *}$ significant at a level of $\alpha=0.05 ;{ }^{* * *}$ significant at a level of $\alpha=0.01$

According to LSV's naïve extrapolation hypothesis, high return performance portfolios (as determined by E/P and $\mathrm{B} / \mathrm{M}$ ) should exhibit low past growth rates and relatively higher future growth rates. Conversely, growth portfolios should exhibit high past growth rates and relatively lower future growth rates. As shown in Table 2, high past earnings growth ranks (REPSGP) and low future growth ranks (REPSGF) are associated with high E/P (value) portfolios, whereas rankings of low past earnings growth rates and high future growth rates are associated with growth portfolios. For asset growth and sales growth, low past and future growth is associated with the E/P value portfolios. The persistence of these growth rates for the E/P value and growth reinforces the earlier results from LSV's (1994) naïve 
extrapolation hypotheses. Slow growth appears associated with higher returns in the sense that E/P portfolios growth patterns persist from past to the future.

Table 2: Mean Data for Long Horizon Holding Period Returns and Selected Rankings

This table provides mean data for the long horizon holding period returns and quintile rankings for the fundamental Earnings-toPrice (EP) and Book-to-Market (BM) variables. Each Panel is segregated into quintiles according to EP or BM rankings. Panel A shows the results for the EP rankings while Panel B shows the results for the BM rankings. Variable acronyms are as follows. $H P R$ represents the 5-year holding period returns for firms in each quintile portfolio. REPSGP (REPSGF) is the ranking of the past (future) 5-year earnings per share growth rate calculation. RASSTGP (RASSTGF) is the ranking of the past (future) 5-year total asset growth rate calculation. RSALEGP (RSALEGB) is the ranking of the past (future) 5-year total sales growth rate calculation. RMKT and RPRICE represent the rankings of the market value and stock price of each firm in each portfolio formation year respectively. C.V. is the coefficient of variation of the cross-sectional 5-year holding period returns in each quintile.

Growth rates were calculated using OLS regressions to fit a line between the logarithm of the most recent reported value of earnings, assets or sales with the previous or future 5 years reported values. Earnings per share and book value data were obtained from COMPUSTAT for each firm at its fiscal year end. Price data were obtained from CRSP and adjusted for stock splits or dividends when firms were added to the portfolio 3 months after fiscal year end. Holding period returns are buy-and-hold returns and include all dividends and distributions

Panel A: Earnings-to-price (EP) quintile rankings

\begin{tabular}{|c|c|c|c|c|c|}
\hline & $\begin{array}{c}\text { Growth Firms } \\
1\end{array}$ & 2 & 3 & 4 & $\begin{array}{c}\text { Value Firms } \\
5\end{array}$ \\
\hline HPR & 112 & 121 & 131 & 141 & 154 \\
\hline C.V. & 162 & 145 & 142 & 121 & 135 \\
\hline REPSGP & 1.58 & 2.15 & 2.01 & 2.02 & 2.23 \\
\hline REPSGF & 2.64 & 2.19 & 1.93 & 1.78 & 1.45 \\
\hline RASSTGP & 2.33 & 2.31 & 2.00 & 1.67 & 1.69 \\
\hline RASSTGF & 2.22 & 2.26 & 2.03 & 1.87 & 1.62 \\
\hline RSALEGP & 2.17 & 2.16 & 1.92 & 1.81 & 1.94 \\
\hline RSALEGF & 2.48 & 2.28 & 2.03 & 1.70 & 1.52 \\
\hline RMKT & 1.90 & 2.25 & 2.02 & 1.94 & 1.89 \\
\hline RPRICE & 1.86 & 2.22 & 2.11 & 2.06 & 1.75 \\
\hline
\end{tabular}

Panel B : Book-to-market (BM) quintile rankings

\begin{tabular}{|c|c|c|c|c|c|}
\hline & $\begin{array}{c}\text { Growth Firms } \\
1 \\
\end{array}$ & 2 & 3 & 4 & $\begin{array}{c}\text { Value Firms } \\
5 \\
\end{array}$ \\
\hline HPR & 108 & 117 & 121 & 146 & 166 \\
\hline C.V. & 155 & 139 & 134 & 130 & 139 \\
\hline REPSGP & 2.91 & 2.35 & 1.87 & 1.58 & 1.29 \\
\hline REPSGF & 2.25 & 1.94 & 1.80 & 1.88 & 2.13 \\
\hline RASSTGP & 2.77 & 2.33 & 1.86 & 1.56 & 1.48 \\
\hline RASSTGF & 2.68 & 2.28 & 1.91 & 1.64 & 1.49 \\
\hline RSALEGP & 2.72 & 2.21 & 1.83 & 1.73 & 1.52 \\
\hline RSALEGF & 2.63 & 2.23 & 1.87 & 1.59 & 1.69 \\
\hline RMKT & 2.56 & 2.17 & 1.98 & 1.91 & 1.38 \\
\hline RPRICE & 2.57 & 2.17 & 2.07 & 1.86 & 1.32 \\
\hline
\end{tabular}


Results across the $\mathrm{B} / \mathrm{M}$ quintiles are similar to the $\mathrm{E} / \mathrm{P}$ results and suggest that growth patterns are also persistent across B/M quintiles. This result confirms compatibility with the naïve extrapolation hypothesis; however, this panel sorts by B/M and is only an indirect test of the growth hypothesis. Although low (high) performers are associated with high (low) past growth in earnings, future earnings growth shows a U-shaped pattern, suggesting firms may move to either extreme. The past and future growth rates in assets and sales rankings are similar across B/M quintiles to the E/P ranking across quintiles.

Since firm size and low price effects are known to affect results of similar studies, rankings of market value and stock prices are also included. There appears to be no size or low-price effects confounding the E/P results. There are, however, small firm and low price effects in the B/M groupings. Size and price rankings are therefore included in the remaining analyses to examine any systematic impact on the results. In sum, these results indicate that the relationship between $\mathrm{B} / \mathrm{M}$ and $\mathrm{E} / \mathrm{P}$ with returns and growth is similar to earlier studies. Next, past growth and its impact on holding period returns are examined as the LSV hypothesis is extended.

Table 3 reports the future holding period return after dividing the data into quintiles according to historical growth. The slowest growing 20\% (quintile 5-value firms) of earnings per share (Panel A) and assets (Panel B) have the highest future holding period return with the holding period return declining monotonically as the past growth increases. The relationship between growth in sales (Panel C) and holding period return is similar, with low growth firms exhibiting higher holding period returns. The coefficients of variation $(\mathrm{CV})$ indicate that in each of the past growth panels (A-C) the extreme quintiles (1 and 5) have the largest return variance. In addition, the firms with the slowest past growth (quintile 5) have risk levels, as shown by the CV measure that are lower than the risk of firms with the highest past growth. This observation will become important once the future growth ranks are examined.

Table 3 reports the future growth ranks for each of the past growth quintiles. The data are divided into past growth quintiles. The slowest past growth quintile (the value firms) has an assigned rank of 1.0. The future growth ranks for the lowest growth quintiles are 2.56 for earnings (Panel A), 1.60 for assets (Panel B), and 1.80 for sales (Panel C). This increase in ranking indicates that slow past growth firms increased their growth ranks in the future. The firms with the fastest past growth (growth firms) have future growth ranks of 1.83, 2.52, and 2.63, for earnings, assets, and sales, respectively, indicating that growth ranks have fallen (from a rank of 5) for the fastest growers. Mean reversion of growth rates appears to occur. ${ }^{3}$ If investors extrapolate past growth trends as the future growth estimates, then they err. Fast growers tend to remain relatively fast growers, but their relative growth rates decline, and slow growers tend to grow relatively slowly in the future, but their relative growth rates increase. Mean reversion of growth rates in sales, assets, and earnings supports the hypothesis that competition reduces future growth of fast growers, and lack of competition enhances the growth of slow growers.

If investors expect past growth to continue in the future, investors are practicing naïve extrapolation. Since past growth ranks do not properly predict future growth, naïve extrapolation should produce returns that are inversely related to those based on perfect extrapolations of future growth. Results indicate that returns are higher for the lowest past growth firms. This growth shift suggests that prices of firms with fast past growth are bid up too high by investors naïvely extrapolating past to future growth. Not only are returns higher for firms that grew slowly in the past but also risk, as measured by the coefficient of variation (CV), is lower compared to the firms that grew the fastest. This result indicates that although a higher level of risk is associated with high growth firms, higher returns are not necessarily so related. This contradiction of the risk/return tradeoff is one explanation of why value investment strategies appear to be superior to growth investment strategies.

The inverse relationship between past growth and holding period returns also adds support to the competitive market explanation. High past growth, no matter whether defined as growth in earnings, assets or sales appear to induce others to enter the marketplace, dampening prospects, and likewise, holding period returns. Although, high growth rates in assets and sales tend to persist into the future, they revert to a mean rate that does not translate into higher investment returns. 


\section{Table 3: Mean Data for Long Horizon Holding Period Returns and Growth Variables}

This table provides mean data for the long horizon holding period returns and quintile rankings for the growth variables. Each Panel is segregated into quintiles according to previous 5-year Earnings Per Share (REPS), Total Assets (RASST), or Total Sales (RSALE) growth rankings. Panel A shows the results for the EPS growth rankings, Panel B shows the results for the Total Assets growth rankings, and Panel $\mathrm{C}$ shows the results for the Total Sales growth rankings. Variable acronyms are as follows. $H P R$ represents the 5-year holding period returns for firms in each quintile portfolio. REPSGP and REPSGF are the rankings of the past and future 5-year earnings per share growth rates respectively. RASSTGP and RASSTGF are the rankings of the past and future 5-year total asset growth rates respectively. RSALEGP and RSALEGF are the rankings of the past and future 5-year total sales growth rates respectively. RMKT and RPRICE represent the rankings of the market value and stock price of each firm in each portfolio formation year respectively. C.V. is the coefficient of variation of the cross-sectional 5-year holding period returns in each quintile.

Panel A: Past earnings-per-share (EPS) growth quintile rankings

\begin{tabular}{|c|c|c|c|c|c|}
\hline & $\begin{array}{c}\text { Growth Firms } \\
1 \\
\end{array}$ & 2 & 3 & 4 & $\begin{array}{c}\text { Value Firms } \\
5 \\
\end{array}$ \\
\hline HPR & 112 & 128 & 134 & 139 & 146 \\
\hline C.V. & 156 & 128 & 131 & 137 & 149 \\
\hline REP & 1.95 & 2.09 & 2.40 & 2.30 & 1.25 \\
\hline RBM & 1.25 & 1.50 & 2.03 & 2.44 & 2.78 \\
\hline REPSGF & 1.83 & 1.85 & 1.85 & 1.89 & 2.56 \\
\hline RASSTGF & 2.48 & 2.37 & 1.97 & 1.77 & 1.58 \\
\hline RSALEGF & 2.44 & 2.11 & 1.81 & 1.77 & 1.88 \\
\hline RMKT & 1.88 & 2.28 & 2.21 & 2.00 & 1.64 \\
\hline RPRICE & 1.95 & 2.38 & 2.22 & 1.99 & 1.48 \\
\hline \multicolumn{6}{|c|}{ Panel B: Past asset (RASST) growth quintile rankings } \\
\hline & Growth Firms & & & & Value Firms \\
\hline & 1 & 2 & 3 & 4 & 5 \\
\hline HPR & 119 & 122 & 129 & 137 & 153 \\
\hline C.V. & 195 & 144 & 117 & 113 & 131 \\
\hline REP & 1.42 & 1.93 & 2.13 & 2.36 & 2.16 \\
\hline RBM & 1.28 & 1.72 & 2.02 & 2.34 & 2.63 \\
\hline REPSGF & 2.13 & 1.97 & 1.88 & 1.92 & 2.10 \\
\hline RASSTGF & 2.52 & 2.10 & 1.96 & 1.82 & 1.60 \\
\hline RSALEGF & 2.70 & 2.14 & 1.86 & 1.65 & 1.65 \\
\hline RMKT & 1.98 & 2.12 & 2.15 & 2.07 & 1.67 \\
\hline RPRICE & 1.72 & 2.12 & 2.22 & 2.16 & 1.79 \\
\hline \multicolumn{6}{|c|}{ Panel C: Past sales (RSALE) growth quintile rankings } \\
\hline & Growth Firms & & & & Value Firms \\
\hline & 1 & 2 & 3 & 4 & 5 \\
\hline HPR & 130 & 124 & 126 & 140 & 139 \\
\hline C.V. & 167 & 148 & 107 & 132 & 142 \\
\hline REP & 1.64 & 2.02 & 2.18 & 2.20 & 1.96 \\
\hline RBM & 1.43 & 1.76 & 1.94 & 2.28 & 2.60 \\
\hline REPSGF & 2.06 & 1.91 & 1.88 & 2.03 & 2.13 \\
\hline RASSTGF & 2.53 & 2.07 & 1.94 & 1.83 & 1.63 \\
\hline RSALEGF & 2.63 & 2.00 & 1.81 & 1.76 & 1.80 \\
\hline RMKT & 1.91 & 2.13 & 2.16 & 2.06 & 1.74 \\
\hline RPRICE & 1.73 & 2.10 & 2.17 & 2.18 & 1.83 \\
\hline
\end{tabular}

To investigate the extrapolation issue in further detail, naïve extrapolation errors and the impact on future holding period returns are examined. LSV indicate that naïve extrapolation may help explain the E/P and B/M investment puzzles. This naïve extrapolation approach is fertile research territory since no readily available consensus expectation of estimates on sales and assets growth rates exist, and this sample includes many smaller firms that have no analyst estimates. Although no test of any particular asset pricing model is proposed, regressing 
long horizon holding period returns on growth rate extrapolation errors, along with other variables, may provide useful information on the role of growth. The particular relationship investigated is between holding period returns, fundamental variables, naïve growth rate indicators, errors associated with naïve extrapolations, and size related variables. The regression setting is specified by Equation (1).

$\mathrm{HPR}_{\mathrm{it}}=\alpha+\beta_{1} \mathrm{~B} / \mathrm{M}_{\mathrm{it}}+\beta_{2} \mathrm{E} / \mathrm{P}_{\mathrm{it}}+\Sigma \beta_{\mathrm{j}} \mathrm{NGR}_{\mathrm{jit}}+\Sigma \beta_{\mathrm{j}} \mathrm{NGRE}_{\mathrm{jit}}+\Sigma \beta_{\mathrm{k}} \mathrm{Size}_{\mathrm{kit}}+\varepsilon_{\mathrm{it}}$

$\mathrm{B} / \mathrm{M}$, and $\mathrm{E} / \mathrm{P}$ are the valuation variables, $\mathrm{NGR}_{\mathrm{j}}$ represents the naïve growth rate factors, which use past growth rates as the proxy, and $\mathrm{NGRE}_{\mathrm{j}}$ represents the naïve growth rate errors. The subscript $\mathrm{j}$ represents earnings, sales and assets factors. Size $\mathrm{k}_{\mathrm{k}}$ represents market value or price level. The subscripts $\mathrm{i}$ and $\mathrm{t}$ correspond to firm $\mathrm{i}$ at time $\mathrm{t}$.

Two regressions are examined to test the impact of including the naïve extrapolation error. In the constrained regression the naïve extrapolation error parameters are restricted to zero, while in the unconstrained regression the naïve extrapolation error parameters are not restricted. These regressions also contain fundamental valuation variables, size variables, and growth variables. The results of the cross-sectional regression analysis are reported in Table 4. The constrained regression is statistically significant, but the adjusted $\mathrm{R}^{2}$ is quite low $(0.012)$. A test for restricting the naïve error parameters rejects the null that they are equal to zero $(\mathrm{F}-\mathrm{value}=796)$. The explanatory power of the unconstrained model is substantially larger than the constrained one (adjusted $R^{2}$ of 0.215 vs. 0.012 ), and more importantly, there is an indication that naïve growth rate extrapolations help explain long horizon returns.

The naïve growth rate errors (from the unconstrained regression) for earnings, sales, and assets are all positive and significant contributors to explaining the holding period return (HPR). Naïve growth expectations in earnings, assets and sales are also significant in explaining holding period returns. The $\mathrm{B} / \mathrm{M}$ and $\mathrm{E} / \mathrm{P}$ fundamental valuation variables are statistically significant, but the size variable is not significant. It is interesting to note the differences in the constrained and unconstrained results for $\mathrm{E} / \mathrm{P}$ and size. The size variable loses and the $\mathrm{E} / \mathrm{P}$ variable gains significance, because the naïve growth errors in conjunction with the other variables better explain the return generating process. The interrelationships between the error variables, growth, and the fundamental variables seem to have some common variability. Growth, especially growth rate extrapolation errors, and B/M (and E/P to a lesser extent) are important factors explaining long-term returns.

In sum, past growth, $\mathrm{B} / \mathrm{M}$ and especially the difference between past and future growth (as reflected in the naïve growth errors), are important in explaining holding period returns. The role played by growth may be particularly important because of the errors made when investors develop future estimates. The statistical significance of the naïve growth rate errors (NGRE's) indicates that market participants consider deviations from naïve growth rate extrapolations in making investment decisions. The positive coefficients indicate that holding period returns fall for firms failing to reach growth expectations. Firms exceeding naïve extrapolation growth forecasts have superior returns. It is likely that investment participants incorporate changes in expectations before the end of a 5-year holding period horizon. Incorporating errors of naïve extrapolations represents rational behavior in an efficient market context and provides support for the LSV contention that naive extrapolation errors affect long horizon holding period returns. This result applies to all the growth definitions and demonstrates a possible benefit from explicitly incorporating growth as a factor in investment decision making.

\section{CONCLUSION}

Historical growth rates in earnings, sales, and assets are important factors explaining future growth and future long-term returns. Future growth is higher for fast growing firms, but there is a relative decline in rank for firms that grow faster and a relative increase for firms that grow slowly. Growth appears to be mean reverting. Consistent with a competitive market explanation, the results indicate an inverse relationship between past growth rates and future growth rates and holding period returns. Slow growth firms produce higher returns than fast growth firms because their growth is relatively faster than in the past and because their share prices have been marked down to reflect a belief of future slow growth. Firms that exhibit high levels of past growth potentially entice competition that lowers stock market performance in the future. 


\section{Table 4: Cross-Section Regression Results}

This table presents the cross-sectional regression results using 5-year holding period returns as the dependent variable. 9,197 firmyears of data were used in the analysis. The actual regression is represented by Equation (1): $\operatorname{HPR}_{\mathrm{it}}=\alpha+\beta_{1} \mathrm{~B} / \mathrm{M}_{\mathrm{it}}+\beta_{2} \mathrm{E} / \mathrm{P}_{\mathrm{it}}+$ $\Sigma \beta_{\mathrm{j}} \mathrm{NGR}_{\mathrm{jit}}+\Sigma \beta_{\mathrm{j}} \mathrm{NGRE}_{\mathrm{jit}}+\Sigma \beta_{\mathrm{k}}$ Size $_{\mathrm{kit}}+\varepsilon_{\mathrm{it}} . \quad B / M$ represents book-to-market and $E / P$ represents earnings-to-price ratios. $\quad N G R$ and $N G R E$ represent naïve growth rates (as generated by past growth rates) and naïve growth rate errors (as generated by differences between past and future growth rates) respectively. Size represents either market value or firm price.

\begin{tabular}{|c|c|c|c|}
\hline Variable & Constrained Regression & Unconstrained Regression & Model Test \\
\hline Intercept & $\begin{array}{c}1.365 \\
(<0.0001)\end{array}$ & $\begin{array}{c}1.457 \\
(<0.0001)\end{array}$ & \\
\hline Earnings-to-Price & $\begin{array}{c}0.040 \\
(0.329)\end{array}$ & $\begin{array}{c}0.072 \\
(0.047)\end{array}$ & \\
\hline Book-to-Market & $\begin{array}{c}0.002 \\
(0.001)\end{array}$ & $\begin{array}{c}0.002 \\
(0.003)\end{array}$ & \\
\hline Past Earnings Growth & $\begin{array}{c}-0.577 \\
(<0.0001)\end{array}$ & $\begin{array}{c}-0.510 \\
(<0.0001)\end{array}$ & \\
\hline Naïve Earnings Growth Error & NA & $\begin{array}{c}3.906 \\
(<0.0001)\end{array}$ & \\
\hline Past Asset Growth & $\begin{array}{c}-2.384 \\
(<0.0001)\end{array}$ & $\begin{array}{c}-3.026 \\
(<0.0001)\end{array}$ & \\
\hline Naïve Asset Growth Error & NA & $\begin{array}{c}1.837 \\
(<0.0001)\end{array}$ & \\
\hline Past Sales Growth & $\begin{array}{c}2.749 \\
(<0.0001)\end{array}$ & $\begin{array}{c}2.568 \\
(<0.0001)\end{array}$ & \\
\hline Naïve Sales Growth Error & NA & $\begin{array}{c}1.749 \\
(<0.0001)\end{array}$ & \\
\hline Market Value & $\begin{array}{l}-1.6 \mathrm{E}-5 \\
(0.008)\end{array}$ & $\begin{array}{c}-8.13 e-6 \\
(0.101)\end{array}$ & \\
\hline Price & $\begin{array}{l}8.42 \mathrm{E}-5 \\
(0.630)\end{array}$ & $\begin{array}{c}-1.67 \mathrm{e}-4 \\
(0.287)\end{array}$ & \\
\hline Error Sum of Squares & 31393 & 24916 & \\
\hline Model Sigma $^{2}$ & 3.416 & 2.712 & \\
\hline Model F-value & $\begin{array}{c}16.713 \\
(<0.0001)\end{array}$ & $\begin{array}{l}253.508 \\
(<0.0001)\end{array}$ & \\
\hline Adjusted $\mathrm{R}^{2}$ & 0.012 & 0.215 & \\
\hline Restriction Test & & & $\begin{array}{c}795.907 \\
(<0.0001)\end{array}$ \\
\hline $\begin{array}{l}\text { The restriction test is: } \\
\text { restrictions, } 3 .(T-K) \text { represents }\end{array}$ & $\begin{array}{l}\text { r Sum of Squares-Unconstainec } \\
\text { nconstrained Error Sum of Squar } \\
\text { egrees of freedom of the } u\end{array}$ & $\begin{array}{l}\frac{\text { Sum of Squares }) / J}{-K)} \sim F_{J, T-K} . J \mathrm{r} \\
\text { strained regression, 9,186. }\end{array}$ & e number of model \\
\hline
\end{tabular}

Naïve growth rate extrapolation errors are positively related to holding period returns. This conclusion extends and is consistent with LSV's suggestion that value firms will outperform growth firms because investors naïvely extrapolate both slow and fast historical growth rates. Through time, once errors in naïve extrapolations are realized, investors adjust, causing value firms to outperform growth firms. Thus, investors' growth errors are important factors explaining why value strategies outperform growth strategies. Extrapolation errors, and not necessarily risk differences, cause value strategies to consistently have higher returns than growth strategies. These results support both a competitive market explanation and a behavioral explanation of investment returns.

Further research should focus on three key issues. One issue is the correspondence between past earnings growth and estimated earnings growth. We focus on past earnings growth as the best estimate of future earnings. Analysts' estimates are widely available and there may be value added by analysts in their estimating process. Second, growth in cash flows may be more important than growth in earnings and the differences between the two measures should be examined. Finally, the definition of earnings has changed, with core earnings being more relevant to 
valuations. The new S\&P definition of core earnings provides a more strict definition or what is considered to be revenues and expenses and should provide improved reliability of earnings numbers? And perhaps the relationships observed in the past may change? The conclusions formed in the paper depend on the data available and extensions over time will allow study of the bubble of the late 1990s and the deep stock declines of 2001-2003. Long-term analyses should help explain why returns are affected by investor behavior that may not be rational.

This paper has benefited from comments by conference participants at the 1998 International Financial Management Association Meeting, the 1996 Southwestern Finance Association meeting, and the 1996 Financial Management Association meeting. We are grateful for comments from Ian Cooper, William H. Brigham and Swaminathan Badrinath. All errors are our own.

\section{REFERENCES}

1. Basu, S., "Investment Performance of Common Stocks in Relation to Their Price Earnings Ratios: A Test of the Efficient Market Hypothesis," Journal of Finance, Vol. 32, No. 3, pp. 663-682, 1977.

2. Bauman, Scott, Mitchell Conover and Robert Miller, "Growth versus Value and Large-Cap versus Small-Cap Stocks in International Markets," Financial Analysts Journal, Vol. 54, No. 2, pp. 27-36, 1998.

3. Brigham, E. and J. Houston, Fundamentals of Financial Management, $10^{\text {th }}$ edition, Southwestern, pp. 653654, 2004.

4. Capaul, C., I. Rowley and W. F. Sharpe, "International Value and Growth Stock Returns," Financial Analysts Journal, Vol. 49, No. 1, pp. 27-36, 1993.

5. Chan, L., Y. Hamao and J. Lakonishok, "Fundamentals and Stock Returns in Japan," Journal of Finance, Vol. 46, No. 5, pp. 1739-1764, 1991.

6. $\quad$ Chan, L., J. Karceski and Josef Lakonishok, "The Level and Persistence of Growth Rates," Working Paper 8282, National Bureau of Economic Research, 2001.

7. $\quad$ DeBondt, W., and R. Thaler, "Does the Stock Market Overreact?" Journal of Finance Vol. 40, No. 3, pp. 793805, 1985.

8. $\quad$ "Further Evidence on Investor Overreaction and Stock Market Seasonality," Journal of Finance, Vol. 42, No. 3, pp. 557-581, 1987.

9. Dechow, P. M., and R. G. Sloan, "Returns to Contrarian Investment Strategies: Tests of Naive Expectations Hypotheses," Journal of Financial Economics, Vol. 43, No. 1, pp. 3-27, 1997.

10. Fama, E. and K. French, "The Cross Section of Expected Stock Returns," Journal of Finance, Vol.46, No. 1, pp. 427-465, 1992.

11. Fuller, R., L. Huberts and M. Levinson, "It's Not Higgledy-Piggledy Growth!" Journal of Portfolio Management, Vol. 18, No. 2, pp. 38-45, 1992.

12. Graham, B. and D. Dodd, Security Analysis, McGraw-Hill, New York, 1934.

13. Harris, R. S., and F. C. Marston, "Value Versus Growth Stocks: Book-to-Market, Growth, and Beta," Financial Analysts Journal, Vol. 50, No. 5, pp. 18-24, 1994.

14. Haugen, R. A., The New Finance: The Case Against Efficient Markets, Prentice Hall, Englewood Cliffs, New Jersey, 1995.

15. Haugen, R. A. and N. L. Baker, "Interpreting the Evidence on Risk and Expected Return: Comment," Journal of Portfolio Management, Vol. 19, No. 3, pp. 36-43, 1993.

16. Jaffe, J., D. B. Keim and R. Westerfield, "Earnings Yields, Market Values, and Stock Returns," Journal of Finance, Vol. 44, No. 1, pp. 135-148, 1989.

17. Jegadeesh, N., and S. Titman, "Returns to Buying Winners and Selling losers: Implications of Stock Market Efficiency," Journal of Finance, Vol. 48, No. 1, pp. 65-82, 1993.

18. Lakonishok, J., A. Shleifer and R. W. Vishny, "Contrarian Investment, Extrapolation, and Risk," Journal of Finance, Vol. 49, No. 5, pp. 1541-1578. 1994.

19. LaPorta, R., Lakonishok, J., A. Shleifer and R. W. Vishny, "Good News for Value Stocks: Further Evidence on Market Efficiency," Journal of Finance, Vol. 52, No. 2, pp.859-874, 1997.

20. Lintner, J., and R. Glauber, "Higgledy Piggledy Growth in America," Seminar on the Analysis of Security Prices, University of Chicago, 1967. 
21. Little, I. M. D., "Higgledy Piggledy Growth," Bulletin of the Oxford Institute of Economics and Statistics, Vol. 24, pp. 387-412, 1962.

22. Little, I. M. D., and A. C. Rayner, Higgledy Piggledy Growth Again, Basil Blackwell, Oxford, 1966.

23. Peters, D., "Valuing a Growth Stock," Journal of Portfolio Management, Vol. 17, No. 3, pp. 49-51, 1991.

\section{ENDNOTES}

${ }^{1}$ An alternative explanation relates to the time horizon of investors. Lakonishok, Shleifer and Vishny (1994) imply that most investors have shorter time horizons than those required for value strategies. They suggest that investors typically look for stocks that earn high abnormal returns in a few months rather than over a longer investment period. Investors are too myopic to successfully implement a value investing strategy. Particularly, institutional investors are hypothesized to focus on short-term (quarterly) results since they must produce results to retain their employment. Haugen (1995) also suggests that the time frame of institutional investors is kept short-term. He also finds that over longer time periods, value strategies outperform growth strategies.

${ }^{2}$ The inverse relationship between $\mathrm{B} / \mathrm{M}$ and growth can be shown as follows. Basic valuation theory implies $(\mathrm{k}=\mathrm{D} / \mathrm{P}+\mathrm{g})$. If one multiplies and divides $\mathrm{P}$, the market price, by $\mathrm{B}$, the book value, then rearranges, the following obtains; $(\mathrm{B} / \mathrm{P})=(\mathrm{B} / \mathrm{D})(\mathrm{k}-\mathrm{g})$. Relabeling $\mathrm{P}$ as $\mathrm{M}$ indicates that high levels of $\mathrm{g}$ generate low $\mathrm{B} / \mathrm{M}$ ratios.

${ }^{3}$ To test for mean reversion, growth rates for period $t-1$ are regressed against growth rates for period $t$. If the growth rates were not mean reverting, the coefficient on the previous period growth rate would equal 1.0. The mean reversion coefficients, however, are all significantly less than one for all regressions and definitions of growth. These regression results support the hypothesis that growth rates are mean reverting. 